Article

\title{
Community Food Growing in Parks? Assessing the Acceptability and Feasibility in Sheffield, UK
}

\author{
Jinvo Nam and Nicola Dempsey * \\ Department of Landscape, University of Sheffield, The Arts Tower, Western Bank, Sheffield S10 2TN, UK; \\ jinvo.nam@gmail.com \\ * Correspondence: n.dempsey@sheffield.ac.uk; Tel.: +44-114-222-0616
}

Received: 19 June 2018; Accepted: 9 August 2018; Published: 14 August 2018

\begin{abstract}
Urbanisation brings with it increased pressure on land and land uses, particularly green spaces. There has been considerable interest in community food growing in green spaces as part of a wide trend for gardening in the UK, which has been found to bring social, health, and well-being benefits. Such activity tends to take place in community-managed gardens and allotments. In light of the context of austerity within which local authority parks departments currently operate, this study tested the acceptability and feasibility of parks as a potential urban setting for Community Food Growing (CFG) in Sheffield, UK. Employing a combination of resident questionnaires and interviews with community groups and professionals, the study results showed localised differences in the acceptability and feasibility of CFG. Residents' propensity to want to get involved in CFG differed by age and household composition, which, if acted on across the city, could significantly change the demographic make-up of parks-based community groups in the city. Barriers to CFG in parks were described by community groups and park managers as security and vandalism, need for resources, and undue pressure on the local authority as land-owner. We discuss the emergent questions around who is best placed to manage urban parks, particularly when the public sector is subject to stringent austerity budget measures. The paper concludes with commentary and recommendations about the importance of governance arrangements if CFG is to be included as part of the activities supported and managed in urban parks.
\end{abstract}

Keywords: community food growing; park management; governance; stakeholder; allotment; Sheffield; UK

\section{Introduction}

Ongoing urbanisation means that over 54 per cent of the world's population now lives in urban settlements rising to a projected 60 per cent by 2030 [1]. This has led to increasing pressure on land and insufficient provision of green spaces in many towns and cities [2]. This can lead to a disconnection between people and nature in green spaces, negatively affecting urban residents' health and well-being [3,4]. As such, this pressure on urban space points to a need for maximising the benefits from existing green spaces. One way to harness the benefits of urban natural resources has been identified as food growing in cities [5,6], which can also help safeguard and protect green spaces against increasing urbanisation [7]. As health and wellbeing research grows in its focus, gardening is identified as an important and accessible way of connecting with nature to improve physical, psychological, and social health [8]. Food growing activities are found to contribute positive benefits for mental and physical health [9], children's education [10,11], community cohesion and interaction through social gatherings [12,13], as well as addressing environmental problems such as climate change [14]. Food growing also provides animal habitats, contributes to improving air quality and can help prevent over-use of natural resources [15]. Community food growing (CFG) has a long 
history and in the UK can been seen in the success of campaigns such as 'Dig for Victory' during the Second World War.

During the 1930s-1940s, CFG was a manifestation of the (state-led) collective drive to address a lack of resources, particularly during financial crisis [16] and to improve bonds between community and good citizenship [17]. In recent years, and perhaps with impetus from the global financial crisis and the ensuing context of austerity that local authorities currently operate, CFG-related activities are becoming more popular across a wide range of sites in the UK [18]. This has informed the policy context with strategies and instruments such as the National Planning Policy Framework (England) and relevant funding schemes including the Big Lottery's 'Changing Spaces' programme to specifically support projects including community food growing [13].

Community-led initiatives which address the connections between food-growing activities, health and wellbeing include Groundwork's food growing projects, Growing Together, Social Farms \& Gardens (formerly Federation of City Farms \& Community Gardens), as well as the long-standing popularity in England for allotments [19-21]. The 21st century has seen adaptations of CFG such as guerrilla gardening [22,23] and 'Incredible Edible', which originated in Todmorden, Yorkshire, and has been adopted in urban areas around the world [24]. Incredible Edible demonstrates that type of green space in which CFG could occur does not necessarily need to be restricted to allotments, and could be located in, for example, valley land, park edges, playgrounds and abandoned sites [25]. In this way, ongoing urbanisation pressures on urban land use may encourage alternative spaces for food growing in different forms, such as parks [12]. Therefore, this paper aims to identify how acceptable and feasible are CFG practices in the park setting in the city of Sheffield according to different stakeholders. To achieve this aim, we first conducted a literature review focused on the policy context of community food growing and examined existing evidence on park management practices with an exploration of local stakeholder involvement. We then carried out questionnaire surveys with residents, interviews and focus groups with community groups and land managers to gain an understanding of stakeholders' perceptions. The paper presents the research findings and provides a discussion of their implications in light of the ongoing changes to local authority budgets and accompanying changes in urban landscape management practices.

\section{Community Food Growing (CFG): A Socio-Political Activity?}

CFG is based on the premise that locally based groups of people cultivate land together [13,26,27]. There is a long-standing practice of food growing in English cities, which is manifested in ongoing urban food growing initiatives such as 'Feed Leeds' [27] and the London Food Link [28] among others. Local authorities increasingly acknowledge the importance of CFG activities. For example, Sheffield's citywide green and open space strategy (GOSS) explicitly mentions community involvement and partnerships in support of food growing: 'Develop the necessary resources and partnerships to deliver local practical skills training such as for horticulture/ food growing conservation etc.' [29] (p. 65). These activities reflect an overall tendency within the context of green space management in England for local authorities to underline the importance of partnerships involving a range of stakeholders: for example, Sheffield's GOSS highlights a network of national and local public sector and non-governmental organisations (NGOs) and community groups.

Partly, this acknowledgement of CFG is in response to the stipulations of green space funding bodies: local authorities which maximise community involvement cannot gain access to such funding without involving NGOs and community groups. For example, the Big Lottery will only fund projects through its People's Park programme if community groups are involved in park management. This is particularly relevant in - and we argue, due to - the current era of austerity which is significantly affecting park management, and adversely affecting standards of quality (e.g., [30]).

A significant manifestation of local authority involvement in CFG relates to allotments which have a long history in England. The Enclosure Acts of the 18th-19th centuries used the term 'allotment' to refer to small plots of tenanted land for small-scale food cultivation. Allotment plots in the 18th and 19th century were often cultivated by working craftsmen and tradesmen [31], suggesting 
a relatively high level of means, motivation and capacity of allotment holders. As Sheffield's population increased in the 18th century, most housing did not include domestic gardens, so allotment garden plots were located in tracts of land nearby [32]. Today, allotments continue to be popular in the UK with an average of four people waiting for every 100 plots [11]. The National Allotment Society [33] estimates approximately 330,000 allotment plots in the UK, with a required 90,000 plots to meet current demand. Given its long history of local authority involvement in its management, the allotment is a heavily institutionalised manifestation of land preservation to exercise one's right to grow food [34]. Allotments constitute a symbol of the preservation of the right to land for food growing, although today's allotment communities might not perceive themselves as 'explicitly politicised' [35].

Urban food growing activity elsewhere is used directly as a means by communities to claim rights to land, within the prevailing political context of the day, with community gardens emerging in parallel to environmental justice activism in neighbourhoods where communities were not included in mainstream politics [36]. This is testament to how Certomà and Tornaghi [35] describe urban gardening as 'heterogeneous and fragmented' with dynamic governance arrangements and decision-making processes. Allotments constitute a symbol of the preservation of the right to land for food growing by theorising them as 'agents of counter-neoliberal urban transformation' although today's allotment communities might not perceive themselves as 'explicitly politicised' [ibid]. For example, while the more recent guerrilla gardening phenomenon might be seen as a radical and informal approach, Adams et al. [37] describe it as occurring largely in harmony with existing uses of a place and not implicitly challenging the status quo. Elsewhere, Barron [38] argues that community gardens are particularly conducive to resisting neoliberal processes through the aim of advancing spatial justice through non-commodified means of accessing food in non-privatised spaces. What these manifestations are claimed to have in common with other types of community food growing activities and urban agriculture is their embodiment of the Lefebvrian 'right to the city' and a way of taking back land from authorities [39]. As a political act, urban gardening brings people together through socialisation and solidarity [40] and can therefore contribute to building a sense of community. In some cases, CFG activities may help instigate this, for example where there is no or little pre-existing tradition of such collective action, and in other cases it may be a case of individuals achieving their own goals through collective action [39]. Clavin [5] concludes that community gardens are 'not only food-producing spaces but also often politically contested spaces developed in a particular social context'.

Thinking about the relevant national context in this study, England's current National Planning Policy Framework (NPPF) identifies the need to plan for food growing (albeit in parentheses). The NPPF (2012) incorporates a core planning principle to 'promote mixed use developments, and encourage multiple benefits from the use of land in urban areas, recognising that some open land can perform many functions (such as food production)' [41] (p. 7). Elsewhere, planners have been encouraged to support the creation of community garden spaces as responses to local concerns around health and food security, indicating the political support of local social needs [42]. Interestingly, the 2018 NPPF re-draft has removed reference to mixed use development, stating that 'planning policies and decisions should recognise that some undeveloped land can perform many functions, such as ... food production' [43] (p. 34, emphasis added). This constitutes a backward step: 'undeveloped' land has a different meaning to 'open land', to include land earmarked for development which may not lend itself to anything beyond temporary urban agriculture and food growing. Contributors to a recent conference on urban gardening [44] noted their wariness of the capacity of policy to-in isolation-effect increases in community food growing activity, underlining the constraints that urban environments and governance structures currently impose (e.g., regulations) which can favour those groups with the means and capacity to respond to such constraints [45]. This potential NPPF step back-if enacted in the revised Framework-may well contribute to exacerbating the associated injustice and inequity which is highlighted in the literature. This is attributed to the power relations that are 'infused' in all citizen spaces, including those such as community food growing, which may be conceived with the 
specific aim of addressing issues of social and environmental justice $[44,46]$. Where urban greening or food growing projects occur in one place, they can-de facto-have negative impacts for neighbouring groups or places [47]. Indeed, community food growing and associated urban green space projects may contribute to eco-gentrification as an unintended socio-ecological consequence, or as part of planned strategies used by authorities as part of urban renewal aimed at 'clearing up and clearing out' [48]. The next section focuses on the urban park as a potential setting for CFG.

\section{Park Management Models}

To make sense of park management in practice, De Magalhães and Carmona [49] provide a framework of different management models. Their 'state-centred model' describes the typical starting point for public spaces in which a local authority takes responsibility for delivering and maintaining the place, possibly with minimal external resources [49]. While this has traditionally been the case, stakeholder participation has become increasingly popular, marking a shift from past decision-making in which only practitioners or landowners took part [50], which is argued to result in a positive effect and lead to better outcomes for the local population [51]. De Magalhães and Carmona describe this as the 'user-centred model' to explain the involvement of community groups. There have long been organised community groups involved in green space management in England, and the 'user-centred model' currently fits well with national and local government attempts to devolve responsibility and resources from the state [52-54]. For example, because of a reduction in their parks budget of over $90 \%$, Newcastle City Council is currently handing over the management of all its parks (and allotments) to a non-governmental, charitable trust [55]. This is also made manifest in calls for funding and awards, where community involvement is now a prerequisite (as we have discussed earlier). For example, standards for green spaces to be awarded with a Green Flag stipulate that local communities must be involved in the decision-making and management process [56]. Community-based organisations with specific interests in the management of open spaces often call themselves 'Friends of Parks' groups (also known as park user groups) [53] (p. 61). The involvement of such groups arguably reflects a closer representation of the perceptions and interests of the general public/ residents through non-governmental organisations and professionals [57,58]. It is necessary that users' perceptions should be reflected in the fundamental aims of managing parks where the aim can potentially be to improve people's mental and physical quality of life. It can be difficult to meet users' preferences for park management because use can differ according to demographic characteristics such as age, gender, past experience and specific individual interests $([59,60]$ pp. 325-326). The representativeness of the members of Friends Groups is called into question, however, when they tend to be retired, white and have interests that don't reflect those of all park users [54]. This points to a wider issue of who has the capacity to volunteer which we return to later in the paper. De Magalhães and Carmona's final model is the 'market-centred model' where management tasks are devolved to private entities. This is discussed in more detail elsewhere [45] and is in use in some English urban parks. For example, Southwark Borough Council in London has contracted out many of its parks management tasks since 1996. Many English parks do have private traders working within them through concession agreements, for example with ice cream traders and cafés. This is a form of income generation from parks which, we would also argue, 'fits' within this market-centred model. There is a spectrum of activities that can generate income from the parks and depend on the nature of the park itself, ranging from e.g., car parking, tennis court hire, and hiring space for events. In some places, this can be the main source of income for a park. For example, Potters Field Park in London is in a high-profile location on the south bank of the River Thames and generates income from hire days throughout the year of its space for events such as cultural festivals and filming locations for TV and film [61].

Collaboration in decision-making is also stressed in the concept of 'MSI (Multi-Stakeholder Involvement)' which is defined as a harmonic collaboration among actors which can be influenced by urban green space development to pursue perceived goals [50]. De Magalhães and Carmona [49] conclude that the inter-relationship between the state-, market- and user-centred models could 
contribute to maximising the advantages of effective public space management. We use this theoretical framework of public space management in our examination of CFG within the urban park context, which involves an identification of the stakeholders involved. The stakeholders involved in CFG tend to be community groups, local authority and users [25]. Other stakeholders such as schools/ university and non-for-profit organisations can take part, for example the charity Groundwork works in various English cities with community groups on CFG schemes [27]. While there is anecdotal evidence that CFG could take place in parks, forming a potential alternative park management practice, there have been no studies examining the acceptability and feasibility of this in parks. Our study aims to address this gap in knowledge and we follow Certomà and Tornaghi's [35] recommendation and select a specific context-urban district parks in Sheffield—-to contribute to understanding the feasibility and acceptability of urban food growing in situ.

\section{Materials and Methods}

\subsection{Measuring Acceptability and Feasibility}

To examine the acceptability and feasibility of CFG, it was necessary to develop these two broad concepts to elicit indicators (Table 1).

Table 1. The indicators of acceptability and feasibility.

\begin{tabular}{|c|c|c|c|}
\hline \multirow{3}{*}{ 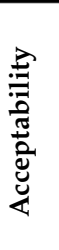 } & \multirow{3}{*}{ 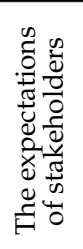 } & Risk & $\begin{array}{l}\text { Extent to negative outcomes } \\
\text { Unpredictable strategic outcomes } \\
\text { Public concern }\end{array}$ \\
\hline & & Returns & $\begin{array}{l}\text { Benefits } \\
\text { A measure of financial effectiveness }\end{array}$ \\
\hline & & Reaction & Extent of positive and negative reaction from stakeholders \\
\hline \multirow{3}{*}{ 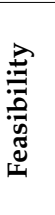 } & \multirow{3}{*}{ 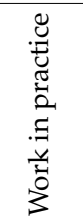 } & Resources & Funding requirement \\
\hline & & People & $\begin{array}{l}\text { Skills, knowledge and experience: work organisation, } \\
\text { rewards, relationships, training development and } \\
\text { recruitment and promotion }\end{array}$ \\
\hline & & Integration & Management of resources \\
\hline
\end{tabular}

A review of the relatively small number of studies which examine acceptability and feasibility, showed that definitions are often not provided (e.g., [63-65]) and have not been applied to the context of urban landscape management. We adapted the work by Johnson et al. [62], who conceptualise the meaning of acceptability and feasibility in their 'Evaluating Strategy' for application in different contexts. According to Johnson et al., [ibid], acceptability is defined as whether the expected performance outcomes of a proposed strategy meet the expectations of stakeholders, for instance, positiveness and negativeness, reaction to proposed strategy, public concern and benefits to stakeholders. A similar definition of acceptability is found in Mendenhall et al. [66], where acceptability is regarded as the demands and benefits of stakeholders. Feasibility is concerned with whether a strategy could work in practice [62]. To understand feasibility, Johnson et al. identify the need to collect data on people's skills, knowledge and experience as well as funding requirements. The feasibility of practice, therefore, needs to be considered in terms of the ability to obtain and integrate new and existing resources. In this research, we therefore adapted this concept of feasibility to examine stakeholders' perceptions of CFG regarding funding for park management, stakeholders' involvement as human resources and other skills and knowledge for park management. The emergent themes derived from interview data were classified and framed in relation to the conceptualised indicators of acceptability and feasibility. The process of analysis allowed us to identify overarching manifestations and provide themes for further discussion. 


\subsection{Site Selection}

To explore acceptability and feasibility of CFG in parks, six parks were selected in Sheffield, the 4th largest city in the UK, which has a total of 83 city, district and local parks [67]. The parks were selected according to the following criteria:

- Park type: district parks were selected as they were felt to be the most likely of park types for CFG to apply as opposed to high-profile city parks and smaller local parks;

- Geographic location: parks located in different areas across the city in both deprived and less deprived areas were selected. According to the Indices of Multiple Deprivation (IMD) (2015), Sheffield has significant differences in terms of deprivation levels of people living in the east (generally more deprived) and west of Sheffield (generally more affluent) [68].

- Community group involvement: to ensure that multiple stakeholders who have an active interest in the overall management of the park could be consulted, we selected parks with an associated community group.

According to these criteria, six parks were selected as study sites: Parson Cross (PCP), Manor Fields (MFP), High Hazels (HHP), Richmond (RMP), Meersbrook Parks (MBP), and Bolehill Recreation Ground (BHP) (Figure 1). They are discussed in more detail in the next section.



Figure 1. Location of selected sites. (Map based on original data adapted from DCLG, 2015 [68].).

\subsection{Characteristics of the Study Sites}

Parson Cross Park (PCP), established in the 1950s, is located in a deprived residential area of Sheffield where anti-social behaviour and vandalism frequently occur in and around park, often attributed to the lack of housing overlooking the park [45]. This problem was exacerbated when economic regeneration in the area in the 2000s led to park improvements but planned housing around the site did not materialise, meaning that anti-social behaviour continues to date. The relevant PCP community group is not directly involved in park management and is involved in local community activities beyond (but including) the park. Independent and fenced allotments named 'Parson Cross Family Garden' are being built in an eastern area of the park. Manor Fields Park (MFP) is another site which suffered from anti-social behaviour over a long period of time. The park was regenerated with government funding from late 1990s-2000s which funded the creation of a social enterprise to manage the park. MFP was transformed, incorporating sustainable drainage 
and ecological planting, from a derelict site to a Green Flag Award winning park (the national standard of good quality green spaces [69]. The Friend of Manor Fields (CoFoMF) formed during the regeneration process and contribute to park management including maintenance, fundraising through event organisation, and holding regular group meetings. The reduced area of Manor Allotments has been improved and fenced since the end of 20th century that initiated part of Dig for Victory during the Second World War in Sheffield, but many parts of the allotments were incorporated into the park due to vandalism frequently. High Hazels Park (HHP) is a Victorian park and originally the grounds of High Hazels House, home of the first mayor of Sheffield. The Friends of High Hazel (CoFoHH) group was established in 1988 and is made up of a small group of active members who have long been involved in managing the park (and the average age of members reflects this). Privately independent and fenced allotments, 'Infield Lane Allotments' are located at the northern side of the park. Richmond Park (RMP) is located in the south-east of Sheffield and was established in 1969. The Friends of Richmond (CoFoRM) formed in 2006 with particular interest in improving the facilities in the park, including the pavilion, seating and playground settings. This involves regular maintenance activities and events organisation to support fundraising for facilities. Small allotments in six plots are placed on a southern area of the park, but the site is unmanaged. Meersbrook Park (MBP) is the oldest park in the sample, established in 1886, forming part of Sheffield's 'green necklace' of municipal parks created between 1875 and 1892. Set within steep topography, the Park is home to a walled garden and Bishop's House, one of the city's oldest buildings. The Meersbrook User Trust Group (CoMBUT) was established in 1998 and has the largest number of active members of all the project sites. Small school groups are involved in food growing activities at the Walled Garden' sited northern area of the park in purpose for education. Finally, Bolehill Recreation Ground known locally as Bolehill Park (BHP) was established in 1976 and was the original location of the Bolehill Quarries. Set in the least deprived area of the sample, the park is also set on a steep incline, incorporating a range of features including a BMX track, two playing fields, and a bowling clubhouse (which was destroyed in a recent arson attack). The Friends of Bolehills (CoFoBH) is a relatively new group, established in 2011, which focuses its activities on small-scale events and regular park maintenance (e.g., litter picks). 'Bolehill Quarry Allotment' is run in the southern side of the park. The allotments are very popular with long waiting lists (See Tables 2 and 3).

Table 2. Characteristics of the study sites (PCP, MFP, and HHP).

\begin{tabular}{|c|c|c|c|}
\hline & Parson Cross Park (PCP) & Manor Fields Park (MFP) & High Hazels Park (HHP) \\
\hline Location in Sheffield & 3.2 miles North of city centre & $\begin{array}{l}1.9 \text { miles South East of } \\
\text { city centre }\end{array}$ & 3 miles East of city centre \\
\hline Site established & 1950 & 1980 & 1895 \\
\hline $\begin{array}{l}\text { Index of } \\
\text { multiple deprivation }{ }^{1}\end{array}$ & $\begin{array}{l}\text { 352th overall } \\
10 \% \text { (Most deprived area) }\end{array}$ & $\begin{array}{l}\text { 820th overall } \\
10 \% \text { (Most deprived area) }\end{array}$ & $\begin{array}{l}\text { 9100th (West) } 30 \% \text { and } \\
\text { 14,187th (South East) 50\% } \\
\text { (Middle deprived area) }\end{array}$ \\
\hline Size of green space & 26 ha & 24 ha & 20 ha \\
\hline $\begin{array}{l}\text { Community } \\
\text { group established }\end{array}$ & 1999 (5 in total/2 active) & 1998 (50/15 active) & 1988 (20/7 active) \\
\hline Member characteristics & $\begin{array}{l}\text { Organising } 15 \text { activities } \\
\text { Managing venue } \\
\text { for funding }\end{array}$ & $\begin{array}{l}\text { Regular maintenance works } \\
\text { Fundraising } \\
\text { Organising events } \\
\text { and festivals } \\
\text { Sharing ideas for better parks } \\
\text { Evaluating park standard } \\
\text { e.g., survey } \\
\text { Managing charity shop }\end{array}$ & $\begin{array}{l}\text { Regular maintenance works } \\
\text { Fundraising from Lottery, } \\
\text { local charity, Sheffield Town } \\
\text { Trust, Sheffield City Trust } \\
\text { Improving facilities e.g., } \\
\text { tennis court } \\
\text { Involving in Family } \\
\text { development project }\end{array}$ \\
\hline $\begin{array}{l}\text { Food growing activities } \\
\text { in or near park }\end{array}$ & $\begin{array}{l}\text { Parson Cross Family } \\
\text { Community Garden: } \\
109 \text { plots, eastern area } \\
\text { inside park, fenced. }\end{array}$ & $\begin{array}{l}\text { Manor Allotments: } 72 \text { plots, } \\
\text { eastern side of near park, } \\
\text { fenced. }\end{array}$ & $\begin{array}{l}\text { Infield Lane Allotment: } 210 \\
\text { plots, northern of near park, } \\
\text { privately fenced. }\end{array}$ \\
\hline
\end{tabular}

${ }^{1}$ Where 1 st is most deprived and 32,841 th is least deprived. 
Table 3. Characteristics of the study sites (RMP, MBP, and BHP).

\begin{tabular}{|c|c|c|c|}
\hline & Richmond Park (RMP) & Meersbrook Park (MBP) & Bolehills Park (BHP) \\
\hline Location in Sheffield & 3.5 miles South East of city centre & 2 miles South of city centre & 2 miles West of city centre \\
\hline Site established & 1969 & 1886 & 1976 \\
\hline $\begin{array}{l}\text { Index of } \\
\text { multiple deprivation }\end{array}$ & $\begin{array}{l}\text { 16,564th (North) } 60 \% \text { and } \\
\text { 8637th (South) } 30 \% \\
\text { (Middle deprived area) }\end{array}$ & $\begin{array}{l}\text { 21,924th (South) } 70 \% \text { and } \\
18,455 \text { th (North) } 60 \% \\
\text { (Middle deprived area) }\end{array}$ & $\begin{array}{l}\text { 27,442th } \\
90 \% \text { (Least deprived area) }\end{array}$ \\
\hline Size of green spaces & 21 ha & 15 ha & 22 ha \\
\hline $\begin{array}{l}\text { Community } \\
\text { group established }\end{array}$ & 2006 (32/7 active) & 1998 (300/20 active) & 2011 (35/10 active) \\
\hline $\begin{array}{l}\text { Activities of } \\
\text { community groups }\end{array}$ & $\begin{array}{l}\text { Regular maintenance works } \\
\cdot \text { Fundraising } \\
\cdot \text { Improving facilities e.g., } \\
\text { tennis court, toilets } \\
\cdot \text { Organising events } \\
\text { and festivals }\end{array}$ & $\begin{array}{l}\text { - Regular maintenance works } \\
\text { - Improving facilities e.g., } \\
\text { playground, skateboard, } \\
\text { football pitch and dog bin } \\
\text { - Fundraising from walled } \\
\text { garden, charity, } \\
\text { Heeley City Farm } \\
\text { - Managing the walled garden } \\
\text { - Organising regular } \\
\text { volunteer session }\end{array}$ & $\begin{array}{l}\text { Regular maintenance works } \\
\text { - Fundraising from Public } \\
\text { Lottery Fund } \\
\text { - Bridge role between council } \\
\text { and residents } \\
\text { - Providing ideas for better park } \\
\text { - Organising events and festivals }\end{array}$ \\
\hline $\begin{array}{l}\text { Food growing activities } \\
\text { in or near park }\end{array}$ & $\begin{array}{l}\text { Richmond Allotment: } 7 \text { plots, } \\
\text { southern of park, New area of } \\
\text { northern side of park }\end{array}$ & $\begin{array}{l}\text { Walled garden: small school } \\
\text { groups are attended to food } \\
\text { growing activities. }\end{array}$ & $\begin{array}{l}\text { Bolehill Quarry Allotment: } \\
15 \text { plots, southern side of near } \\
\text { park, fenced }\end{array}$ \\
\hline
\end{tabular}

${ }^{*}$ Head office of the Sheffield City Council, Parks and Countryside Service has moved out since 2016.

\subsection{Data Collection and Analysis}

A mixed-methods approach was taken in the research: a large-scale household questionnaire survey and a set of semi-structured interviews carried out in 2015 constituted the main data collection methods. The questionnaire asked questions about how residents perceived CFG as a potential park management practice in their local park. Using a mixture of photos and text to provide broad descriptions of CFG [70], the questionnaire also asked whether residents would get involved in CFG as a management practice. We defined groups of specific interest to this study as part of our analytical framework, given the nature of the research questions we are asking. In this way, the questionnaire presented questions about respondents' household characteristics and park use patterns to provide socio-demographic data which could then be used in subsequent analyses to help explain differences in responses. These characteristics include use and non-use of parks, which is an established selection criteria used elsewhere [71-73]. We also analysed the collected data in relation to frequency of park visits [74-76], gender [73,77,78], age [79,80], length of residence [81], and household composition [82-84]. It was a self-completion questionnaire, dropped off at respondents' homes and collected by a researcher a number of days later in an attempt to gain higher than average response rates [85,86]. A total of 2670 questionnaires were distributed to respondents living within $300 \mathrm{~m}$ walking distance of the entrance of each park, with 535 returned questionnaires; 83 in PCP, 81 in MFP, 94 in HHP, 94 in RMP, 86 in MBP, and 97 in BHP, respectively, leading to a final sample of 506 valid questionnaires (average response rate of $19 \%$ ). The response rates varied considerably and were higher in less deprived areas (e.g., 34\% in BHP) and lower in more deprived areas (e.g., 13\% in PCP and $12 \%$ in MFP).

Semi-structured interviews were conducted to explore the perceptions held by community groups and professionals currently involved in parks management. The interview is a well-used method of data collection to shed light on people's perceptions, meanings, definitions of situations and constructions of reality [87]. The interview questions were structured around interviewees' perceptions of CFG as a potential park management practice and probed how acceptable and feasible these stakeholders considered CFG to be within the management of their local park. Representatives from the six community groups were interviewed. Five further interviews were carried out with other 
stakeholders involved in parks management with different affiliations. They were two local authority officers (coded as ProLA-1 and 2), two University academics (ProAC-1 and 2), and a prominent third sector social enterprise involved in urban land management (ProSE). Because of difficulties in interviewing them individually because of how busy they were, a focus group interview was conducted with the six local authority park managers for the parks and their line manager (ProLA-Ms).

The household questionnaire survey data was analysed using Statistical Package for the Social Sciences (SPSS), to conduct a range of statistical tests including one-way ANOVA, Independent samples $t$-test and correlations. To assess effect size, 'Eta squared $\left(h^{2}\right)=S S_{\text {effect }} / S S_{\text {total }}$ ' and 'Cohen's $(d)=M 1-M 2 / \sigma_{\text {pooled }}$ 'were employed. For the interview data, thematic analysis was conducted to better understand the varying perceptions held by stakeholders involved in parks management. Thematic analysis is a commonly used approach to qualitative data analysis, to identify, analyse, and report the themes within data [88,89]. In this way, the data were systematically searched for patterns to provide an illuminating description of the phenomena under scrutiny [90] to glean how acceptable and feasible CFG could be in the six Sheffield parks. We followed thematic analysis as set out by NatCen [91] in their 'Case and Theme Based Approach' (CTBA) to allow for looking down (thematic analysis), looking across (case analysis) and combining both to explore explanations and patterns in responses.

\section{Results}

\subsection{Descriptive Results}

Overall household questionnaire results are presented in Figures 2-4. On average, 41.7\% of respondents would like to see CFG practices in their park. Respondents in MBP were particularly interested in this practice (51.3\%) followed by MFP (44.7\%): the lowest number was RMP $(34.6 \%)$. While $44.4 \%$ of the sample agreed that such practices could contribute to better park management, a much small percentage of respondents $(13.9 \%)$ stated that they would get involved in this practice. However, 30\% of MFP respondents expressed an interest in getting involved in food growing. We asked questions about current food growing activities, with an average of $37.9 \%$ of respondents reporting growing food in their gardens-rising to over $40 \%$ for PCP, RMP, and MBP respondents and nearer $30 \%$ for BHP. An average of $4.3 \%$ of the sample reported having an allotment, which was almost $10 \%$ for BHP respondents. The majority of respondents (54\%) did not engage in food growing in either their garden or an allotment while $3.8 \%$ of the sample did food growing in both. When asked about their involvement in their local community, $13.9 \%$ of the respondents described being involved in local community. This reduced to an average of $3.6 \%$ when asked if respondents took part in community activities specifically contributing to parks or green spaces. There were significant correlations between the indicators of acceptability and feasibility, indicating that respondents who wanted to see CFG activities in their park were more likely to want to get involved in CFG activities and agree that CFG could contribute to better parks management. 


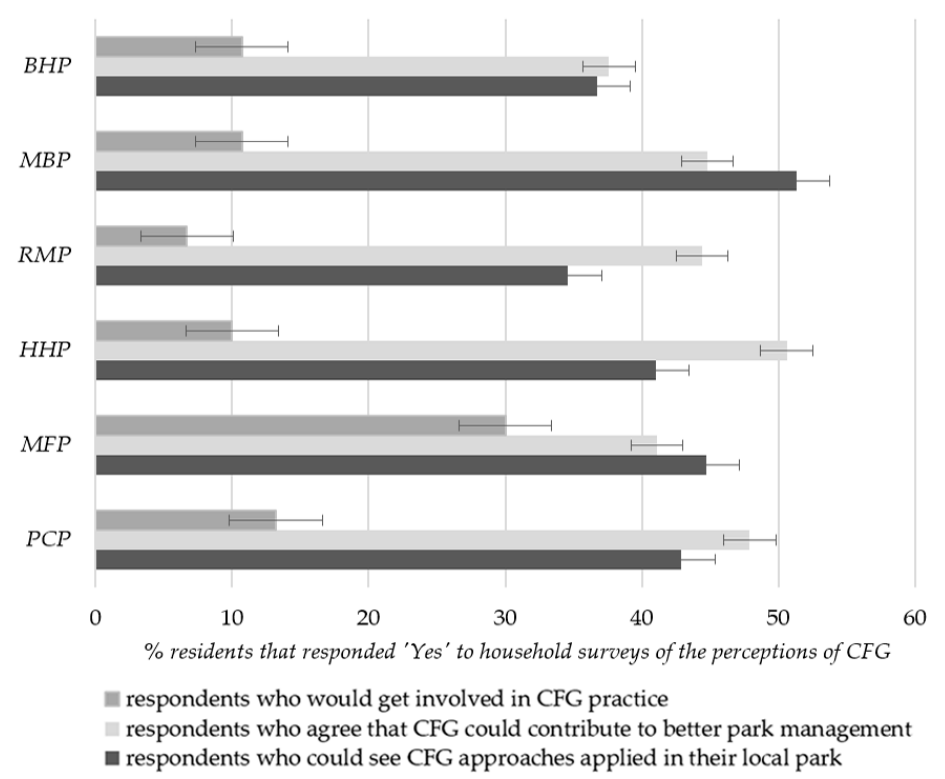

Figure 2. Results of household surveys on the perceptions of residents of six parks.

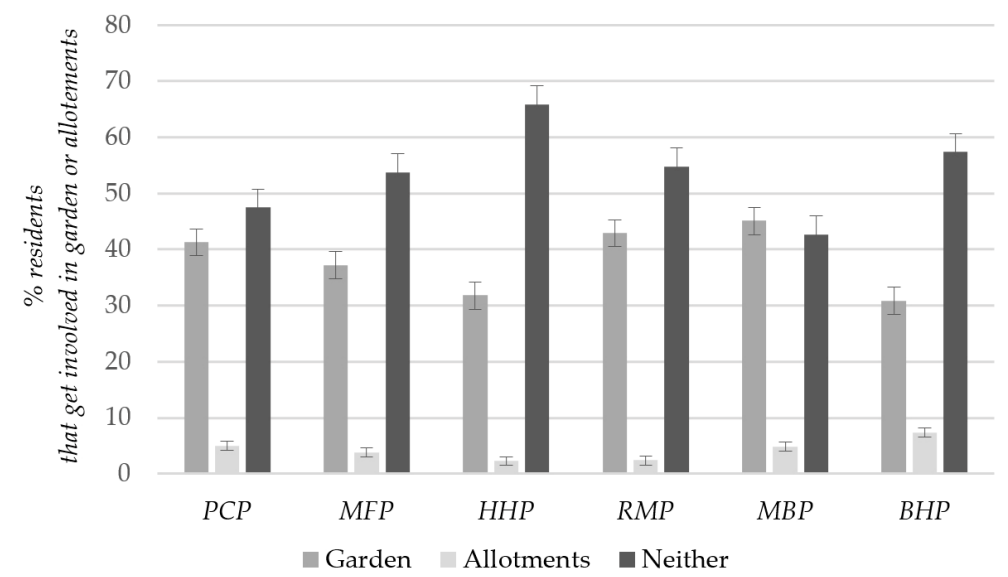

Figure 3. Results on food growing involvement of residents of six parks in garden or allotments.

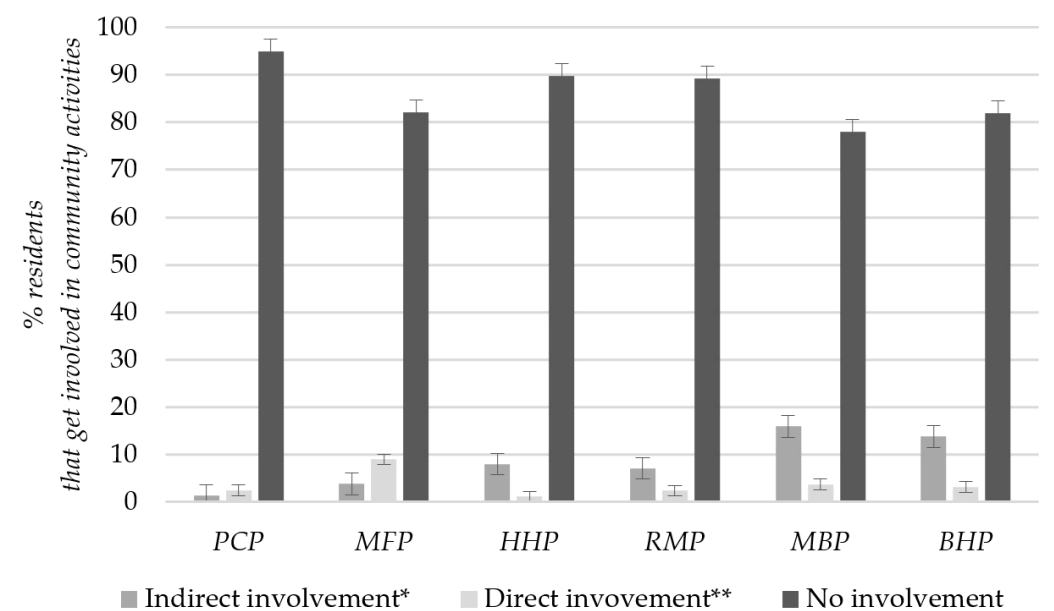

Figure 4. Results on community involvement of residents of six parks. $\left({ }^{*}\right.$ Respondents get involved in local community, not directly in parks or green spaces e.g., local charity, activities, forum, etc. ${ }^{* *}$ Respondents directly involved with parks or green spaces in the local community.). 


\subsection{Acceptability of Community Food Growing}

\subsubsection{Residents' Perceptions of Acceptability}

Statistical tests were conducted to assess the acceptability of CFG and examine whether residents' perceptions of CFG were influenced by their household and socio-demographic characteristics. These analyses were based on the questionnaire responses to 'Could you see this (Community food growing) approaches in your park?' and 'Could this practice (Community food growing) contribute to better park management?' An Independent samples $t$-test was employed to gauge differences in perceptions of the extent to which CFG could contribute to better park management differed significantly between users and non-users, indicating that users were more likely to agree that CFG can make a positive contribution to park management $(t(506)=3.41, p=0.001, d=0.20)$. A one-way ANOVA test revealed that the perceived contribution of CFG to better park management also differed significantly according to age $\left(F(5,447)=2.955, p=0.012, h^{2}=0.032\right)$. Subsequent one-way ANOVA test, post-hoc test ( $p=0.025$ ) showed that older generations (over 45 years) were less likely to accept the practice as a contribution to better park management than residents aged 25-44 years. There is no significant difference of residents' perceptions according to other socio-demographic and socio-economic aspects i.e., gender, length of residence, frequency of park visits, household composition or IMD. We also found no significant difference between responses for residents living near the different parks.

\subsubsection{Community Groups' Perceptions of Acceptability}

Analyses of the community groups' perceptions of the acceptability of CFG show that most groups had a tendency to question the acceptability of this practice due to barriers around security, vandalism and a perceived unenthusiastic local authority, as well as the long-standing popularity of allotments.

For the majority of community groups, CFG was not easy to accept because of the potential security problems it raises in parks. One community group stated that "Food growing is [a] problem, a lot of foods are stolen because there have been no fences around food growing" (CoFoHH). Another group stated, "We have same problems. Tomatoes, some people [take and eat them]" (CoFoRM). Similarly, one of the respondents mentioned uncertainty due to vandalism: "If they are interested in doing something like that absolutely, yeah. Again, it's how you protect that area" (CoPCCD). These security issues were contrasted with the popularity of allotments as fenced-off and secure places. One respondent suggested that, as secured areas, allotments provide something that parks do not: "They've [allotments] got more security than I have on my site. It's just amazing ... That obviously makes them feel safe." (CoFoMF). The importance of the fence is underlined by the Parson Cross community group: "Whereas the allotments have got their own space, they're fenced off; in a park it would be difficult to do that" (CoPCCD). An additional negative aspect relates to the perceived lack of enthusiasm of the local authority to attempt CFG: "Sheffield council is now very behind Community Food Growing project e.g., Incredible Edible. Very behind" (CoFoRM). However, these perceptions were not shared across all the community groups. Perceptions that community groups had about the acceptability of CFG in the community groups in MFP and MBP were more positive in their discussion of the potential of school children's involvement, stating that "We can put some more in there. There was an idea of an edible hedge as well, which I've got plenty of plants to put in ... People are gradually discovering that ... People are picking up on what's available there ... [for] growing food in the park" (CoFoMF).

\subsubsection{Professionals' Perceptions of Acceptability}

Professionals' comments on the acceptability of CFG seemed to reflect the community groups' perceptions. The analysis showed two emergent themes around security and the inconsistent commitment of community groups. 
Professionals mentioned how there have been security problems again such as stolen food and food damaged by vandalism. One local authority respondent stated that "If we put food into some of our park's food growing areas, they would be damaged or they would be vandalized or people would steal the food" (ProLA-2). Another professional concurred that in most cases: "The community food growing. It's an interesting one ... It was tried on [another park in the city ... ]. Those kind of apples get picked a bit" (ProAC-2). These problems seek alternatives in allotments where people grow in their own secure spaces. One academic stated, "I think there's more space in some parks for more allotments. A lot of people do want their own little piece of land where they can grow, and it's secured" (ProAC-2). As highlighted above, allotments are popular with Sheffield residents. Bearing this in mind, the local authority interviewees discussed its plan to extend allotments as opposed to CFG: "Allotments are very, very popular still and we are hoping to put more allotments around the city [especially] where there are fewer of them" (ProLA-2). Other statements support the popularity of allotments, highlighting a lack of demand for CFG: "Anyone obviously can have an allotment and if anyone comes and wants to grow over here, we probably will expand the space ... if this was obviously a very dense housing area with no private gardens, it would be very likely that people coming and saying "could we have space" to incorporate community growing. The situation hasn't happened" (ProSE).

Another emerging theme is the commitment required to manage CFG. Professionals indicated uncertainty about how consistent community groups can be: " . . a lot of these groups tend to think that they start off with a couple of people and start off with the intentions, but they don't follow it through. That is the danger" (ProLA-Ms). One local authority park manager was more specific in stating that community groups tend to move to the next interesting thing. This consistency was also underlined by one of the academics: "You need to just make sure that it's being done consistently, that's really important" (ProAC-2).

\subsection{Feasibility of Community Food Growing}

\subsubsection{Residents' Perceptions of Feasibility}

Statistical tests were conducted to explore the feasibility of CFG in their local parks according to residents who answered the questionnaire question: 'Would you get involved in this practice?'. The findings show that over half the respondents (54\%) would not get involved in CFG practices, with $13.9 \%$ of the respondents reporting they would be willing to get involved.

Residents' perceptions of feasibility differed according to a range of socio-economic characteristics. There was a statistically significant difference found between users and non-users, indicating that park users were more likely to want to be involved in CFG $(t(506)=6.55, p=0.001, d=0.32)$.

An Independent samples $t$-test showed significant differences between gender in involvement in CFG with women more likely to want to get involved in these practices than men $(t(506)=2.40$, $p=0.017, d=0.11$ ). A one-way ANOVA test showed that respondents' propensity to become involved in CFG differed according to age group with significant associations found $(F(5,461)=11.493, p<0.001$, $\left.h^{2}=0.011\right)$. Post-hoc testing $(p<0.001)$ showed that older generations (over 65 years) were significantly less likely to get involved in CFG practice than younger generations.

There was a significant difference, according to length of residence $(F(6,460)=5.684, p<0.001$, $h^{2}=0.007$ ). A one-way ANOVA showed that differences between long-term resident groups (over 30 years) and all other groups, particularly respondents living in the neighbourhood for 6-10 years and less than three years, indicating a significant propensity for shorter-term residents wanting to become involved in CFG practices. One-way ANOVA tests also showed that the potential involvement in CFG practice was influenced by household composition $\left(F(2,458)=4.656, p=0.010, h^{2}=0.019\right)$. Householders living with children were more likely to want to be involved in these practices than householders without children. 
Our final analyses related to differences in perceptions held by respondents around the different parks. There were differences between respondents' propensity to get involved in CFG practices, in particular between MFP and RMP, $\left(F(5,461)=3.861, p=0.002, h^{2}=0.040\right)$. Respondents from MFP were significantly more likely to be involved in CFG practice than those from RMP. This is also affected to some extent by respondents' age and extent of community involvement. A correlation test showed that older people were less likely to want to get involved in CFG practice $(r=0.316, p<0.001): 33.3 \%$ of respondents in MFP were over 55 years old, while $59.5 \%$ of respondents in RMP were in this age group (almost double). The extent of community activity also has some effect on responses around propensity to get involved in CFG practices: $9.1 \%$ at MFP compared to only $2.4 \%$ at RMP were currently involved in park management.

\subsubsection{Community Groups' Perceptions of Feasibility}

Thematic analyses of the perceptions of community groups show that overall, CFG was not highly perceived to be feasible. There are two crucial factors that negatively affect the feasibility of this practice: a lack of monitoring and a lack of facilities for learning skills.

Unsurprisingly, the perceived relationship between CFG, vandalism, and anti-social behaviour in the parks emerged again in the discussions. However, regarding feasibility, this was raised as an issue about who can manage this practice against these negative aspects. One respondent, for instance, stated, "It's how you protect that area while things are being grown because [it] may be vandalised ... " (CoPCCD). Another community groups discussed the difficulty of management after dark: "At night time when people are out and about, dog mess and stuff like that in parks, it's just, it's how you protect them" (CoFoRM).

Interview discussions revealed that CFG practices are of interest to community groups but are perceived as having insurmountable security problems and a lack of facilities. One community group identified a difficulty around learning skills about food growing and not having enough space to facilitate this: "[Food growing] Learning skill is good. But, [there is] a lack of facilities to do this" (CoFoRM).

For this practice to be more feasible in the park, one community group suggested collaboration with allotment groups: "Community food growing was one of the things we were pushing through here. Either with some linking up with the allotment association, or doing something on our own back ... but there's been a cultural shift in the allotment which I want to kind of link in with. I think we'd be okay with that in terms of some of our ideas as a friends group" (CoFoMF). Another community group also suggested working in partnership with the allotment community: "You may be looking at organizations such as LEAF, which is an allotment project that's interested in green space outdoors. Maybe people could set up a project working in partnership with LEAF to do some improvements in the park and then maybe look at how they can link in with [the] community to get some activities and events up and running, so people [come] in and access the park" (CoPCCD). Two sites, MFP and MBP, reported already being in partnership and collaborating with nearby allotments/social enterprises. This suggests that developing/expanding allotments, rather than CFG, is more feasible in the park, based on a collaborative partnership structure to build on the existing and long-standing popularity of allotments.

\subsubsection{Professionals' Perceptions of Feasibility}

Professionals' perceptions of the feasibility of CFG were similar to those of the community groups, focusing around the need for additional resources. Professionals highlighted the maintenance required in CFG and emphasised a lack of people available to monitor the activity. This is underpinned by a shared understanding that CFG is a high maintenance practice: "I think one of the things with some of these things is there might be high inputs later" (ProAC-1) and "Again it [community food growing] needs maintenance. Everyone thinks you can just put in a fruit tree or whatever else in that space ..." (ProLA-Ms). Further, the type of maintenance required needs skills: "It (food growing) becomes much [more] about skills and community for the food" (ProSE). ProLA-2 pointed out that "it is, because in the war, in the second World War, states needed to grow food ... now ... it's a ... very different 
thing". The professionals also comment on different aspects of local authority responsibility: "even though you have community involvement, you may need monitoring by council staff coordination" (ProAC-1). For the social enterprise, local authority responsibility was missing: "food, the very first thing we did here was [food] ... that was managed by the council and it was completely overgrown" (ProSE). When reflecting on past CFG activities in other parts of the city, ProAC-2 highlighted that no single stakeholder took on responsibility: "They [fruit trees] were never really looked after. Who is going to look after it?" This suggests that there is agreement on the extent of maintenance required in CFG, but there is less agreement on how involved the local authority has been in the past, possibly pointing to a different approach in the future.

Continuing austerity measures applied to the council seem to inform professionals' comments, in terms of the perceived limitations that they bring. The perceived need for monitoring which is conducted by the council is widespread which may be because it has long been the council's responsibility. The austerity measures have had interesting effects on parks management and we have very recently seen a growing propensity of community groups to incorporate CFG activities into their parks. For example, Richmond Park now have raised beds for growing herbs and vegetables. The landscape has clearly changed and, in Sheffield and for the moment at least, CFG has become popular enough for funding to be raised for physical changes.

\section{Discussion}

We identify two overarching themes in the findings which we think require further discussion (Figure 5). First, our sample of the general public demonstrated a propensity to support CFG activities in their local parks. This is variably expressed as a perception of its acceptability as an appropriate management practice in their local park, or as an activity they would like to get involved in directly. Second, the way in which CFG has been approached and managed in the past may not be appropriate if it is adopted in parks in the future. This is because of a general acknowledgement that the local authority is severely hampered in its capacity to continue its current landscape management duties, never mind adopt new ones in the guise of CFG. It is therefore clear that our findings challenge the status quo of parks management practices that were prevalent at the time of this study. We unpick the inter-related themes below.

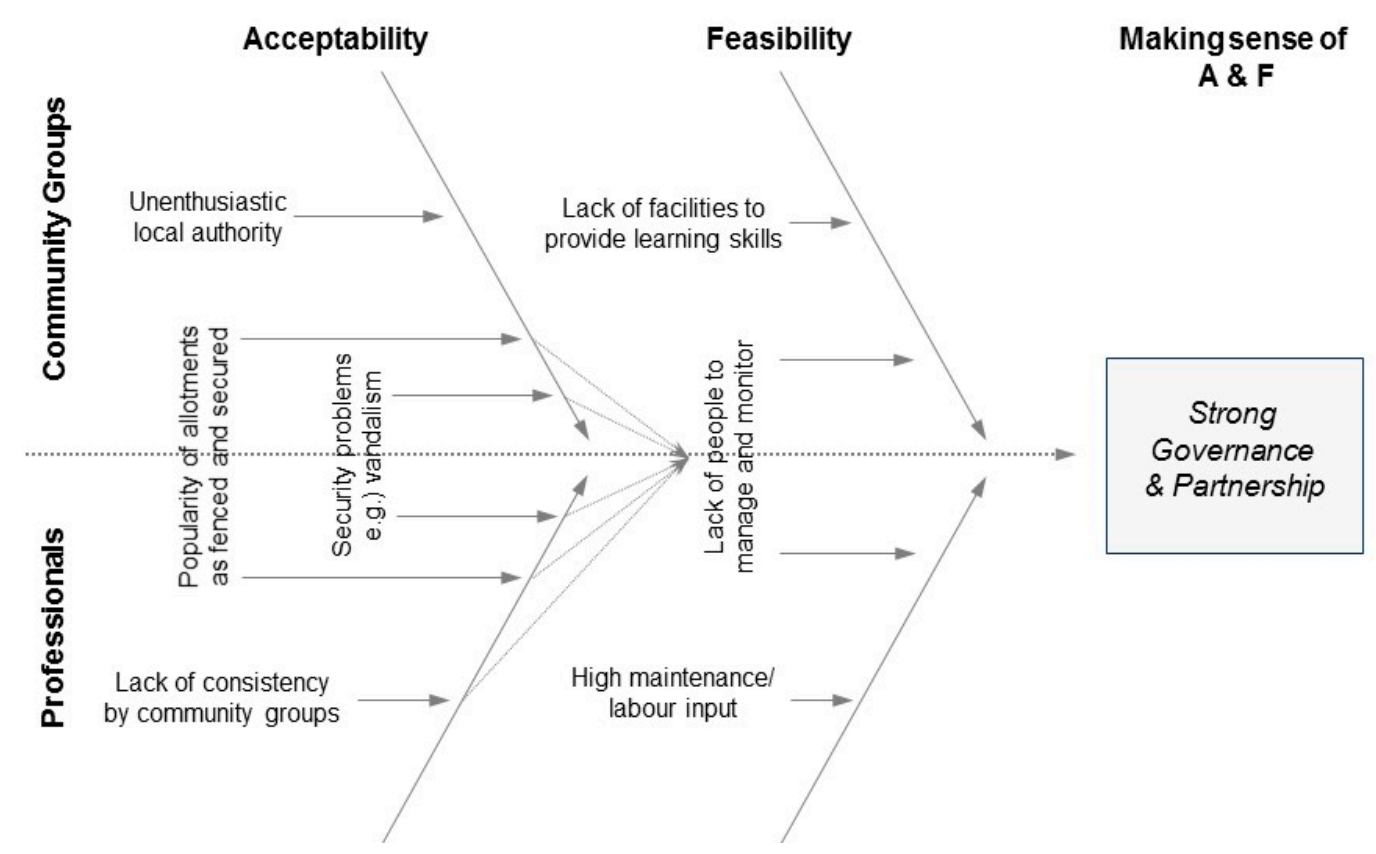

Figure 5. Framing perceptions of community food growing of community groups and professionals. 


\subsection{Community Food Growing in Sheffield's Parks: Varying Levels of Acceptability and Feasibility}

A large proportion of questionnaire respondents showed interest in seeing CFG practices in local park and the findings show that respondents who wanted to see CFG in their park were also more likely to agree that CFG could contribute to better park management and more likely to want to get involved in doing CFG. There were specific differences that should be noted. First, younger questionnaire respondents (25-44 years) were more likely to accept CFG in parks than older (45 years+) respondents. This could be because they have been exposed to a wider range of landscape designs and management practices, including Incredible Edible, which have been applied in different (non-park) settings [24]. Furthermore, it is clear that ideas of stewardship, sustainability and care for the environment are much more prevalent today than in the past, which is (in part) reflected in the changing education curriculum in the UK, as well as increased media coverage on environmental issues, together with improvements in access to a wider range of managed landscapes [6,92]. One might therefore venture that some of the community groups — which tend to be made up of older (65+) active members-favour a more traditional approach to parks management which does not include CFG. This is, however, not the case for all of the parks, and it is worth conducting closer examination of the findings relating to Manor Fields Park. This sub-sample of respondents shows the highest levels of acceptability of CFG across the whole sample, as well as interest in getting involved in CFG which was significantly higher than respondents around all the other parks. Manor Fields Park is not managed according to widespread and 'traditional' practices that one finds in many other parks in the UK. It has aims around sustainable drainage to help alleviate flooding, naturalistic rather than formal planting and active community involvement. We would therefore argue that it is not surprising that CFG, as a non-traditional management practice in parks, might be more popular with this subset of respondents. Scores for acceptability and feasibility were also relatively high for Meersbrook and Parson Cross Parks stakeholders. While these are more traditionally managed parks, Meersbrook has close links to a local social enterprise while both parks, like Manor Fields, have allotments in close proximity. These links to the allotments are not just physical but extend to informal stakeholder partnerships with allotment groups suggesting that future CFG activity might constitute allotment expansion or an extension of CFG activities run by the allotment groups within the parks.

The popularity of allotments which was discussed by community groups could address the concerns they shared with professionals around security, vandalism and anti-social behaviour. Increasing a presence in the park of people involved in park management could reduce these issues, harking back to the 'parkie' who has long been lost in British parks [30]. Providing CFG activities in the park could also potentially address the professionals' concerns around a lack of people available to manage and monitor. However, this latter issue is a wider one of governance, partnership and resources which would need addressing at the local authority level.

\subsection{Challenging the Status Quo of Who is, and Who Should be, Managing Urban Parks?}

Examining the perceptions of community groups and professionals raises interesting questions around the existing governance structures. There seems to be a widely held assumption that the local authority - as the land-owner-is the appropriate (and, for some, only) urban parks manager. With the prevalent austerity measures influencing responses to our questions, it is again perhaps unsurprising that there was a lack of enthusiasm among local authority parks managers about CFG as a park practice given the extra responsibility and monitoring that would require. Professionals highlighted a need for additional resources, and they were not convinced that there could be consistency across groups to take on-and sustain-CFG management. The involvement of allotment groups through land management in parks could help address these issues, given the long-standing governance structures that exist (e.g., supported by the Sheffield and District Allotments Federation and the National Allotments Society, Corby, UK). While the allotment management structure is traditionally based on householders renting the space from the local authority, there are some allotment groups in Sheffield which aim to attract groups of people, rather than individuals, which might be a relevant 
model to extend CFG activities into parks. There would therefore have to be a balance between the park as a public good for all users and private allotment space which tends to be fenced off (e.g., with hedges) to provide a boundary and protection against anti-social behaviour. If a programme of CFG/allotment development were to take place in parks, given our findings of different levels of acceptability and feasibility in relation to different parks, it would make sense to lead with those where acceptability and feasibility were higher. Interestingly though, and after this research was completed, the Friends of Richmond Park — which scored low on acceptability and feasibility-recently created a community garden within the park (and also planted ten fruit trees on site). Based on the Incredible Edible ethos [24], they have constructed raised beds at the edge of the park which are overlooked by nearby housing, and the vegetables produced will be available for people in the community to freely take. Follow-up discussions with the group highlight initial wariness by locals to take on the CFG management. It will be interesting to review how the new management practice is sustained in the park.

The resources that professionals refer to need not be wholly financial nor directed to the land-owning local authority, which is where a challenge to the status quo might be required. As discussed above, other stakeholders have been engaged to manage parks, and this is becoming more prevalent in response to austerity measures in the UK (e.g., HLF [93]). There would be some changes to the governance arrangements-where decision-making tends to lie with the local authority in consultation (and some partnership) with community groups [54]. These might form stewardship agreements which the local authority already has in place with some Friends groups across the city, or to formalise partnerships with the aim of sharing management responsibilities. This points to a wider issue of who should manage parks: according to the NFPGS [94] (p. 1), "the landowner needs to have the responsibility for good maintenance and this then gives the community groups the support they need to bring in the added value to the site". If this is followed, it may be necessary for land ownership to change hands away from local authorities if they are limited as landowners to provide this 'good' level of maintenance. It was outside the scope of our research to ask our participants if they would be willing to take on the ownership of parks, but we can infer from the stakeholder responses that-at the time of this study-there was a widespread assumption that the local authority should own public parks. In this way, it may be initially more acceptable to approach non-governmental stakeholders to explore the potential contribution they could make to park management. This may involve partnerships led by those with land management capacity and also include education stakeholders, given our findings that the links with learning skills (here, food growing) are in demand but not currently provided. This could extend to partnerships involving the city's universities, colleges and local schools where relevant. There are already many examples of, e.g., tree planting activities involving schools, but to a lesser extent do these activities extend to ongoing and sustained parks management.

The ensuing austerity measures and growing pressure on Sheffield's local authority mean it is increasingly unable to manage the land it owns for a wider range of landscape management practices. Since this research was carried out, the responses to ongoing austerity measures on park stewardship and management have included income generating activities such as charging for car parking and the leasing of all tennis courts in Sheffield parks to a national organisation (Parks Tennis) which operates an online system of hourly charging for the use of gated and locked courts. There is therefore scope to explore how 'successful' this involvement of a non-governmental stakeholder in the management of part of Sheffield's parks is perceived to be when one assesses this alongside the long-term impacts (e.g., on the take-up of tennis) in relation to cost-savings to the local authority.

\section{Concluding Observations (and Caveats) About the Potential for CFG in Sheffield's Parks}

The observations, and accompanying recommendations, we make here have resonance for parks, not only in Sheffield but beyond the UK city to other settings, although we do believe that there are contextual differences for other parks which need to be taken into account when reading the following. We are careful to note that we do not personally condone changes in access and ownership of parks 
as public goods if they are managed by groups who are not subject to public scrutiny-outside the scope of this project. However, in light of the current financial climate of austerity and our findings which show that the local authority is currently limited in how well it can manage parks, our findings highlight the potential for a change in governance arrangements. This could mean the local authority stepping back from acting as land-owner-manager to develop partnerships with non-governmental groups/organisations in relation to specific parts of the park (not unlike bowling clubs) which could be developed and formalised e.g., through stewardship agreements. The findings (from MFP) show that the introduction of alternative land management practices can potentially lead to higher levels of acceptability which are correlated with a greater propensity for residents to want to get involved. More research would however be needed to explore to what extent this manifests itself as, for example, increased (and younger) Friends group membership. This also relates to the finding that respondents with families were more likely to want to get involved in CFG, which would dramatically change the average demographics of Friends Groups from the current over-representation of white female over 60s, thereby helping with long-term succession in volunteer-led groups [54]. The formalised involvement of other groups and organisations can help provide a more sustained presence in the park, which could address some of the issues raised by community groups and professionals around anti-social behaviour, vandalism, and security problems which might ensue with the introduction of new park management practices.

The legacy of community food initiatives such as Incredible Edible shows that the appetite for community food growing activities is long-standing-propensity to grow food in their own, shared or leased open spaces. What we do not know is to what extent this propensity might extend itself its reach to public parks and warrant a change in land management governance arrangements. But ongoing changes in the Sheffield parks context shows that once held views about the irrelevance of community food growing in parks can change and indeed have recently manifested themselves in small-scale CFG activities. Future research could examine to what extent these changes are driven at national, local authority and neighbourhood scale to help us understand the sustainability of a wider set of urban landscape management practices in parks.

We acknowledge that there are limitations of the study, particularly around what we were unable to focus on. This was part of a larger doctoral study which involved the examination of a wider range of potential parks management practices. This meant that we were unable to talk to a wide range of stakeholders who have an interest in specific uses of the parks, because we were focused on the perceptions of those involved in a wider set of management practices. For this reason, we could not interview sports groups such as bowling clubs or allotment holders. Therefore, it would be useful in future research to extend the range of interest groups that are represented in studies around urban landscape management practices to further deepen our understanding of existing and potential governance structures that operate both within parks and parks across a city.

Author Contributions: This paper is based on the first author's doctoral research conducted at the University of Sheffield under the supervision of the co-author. Both authors have contributed significantly to the paper.

Funding: This research received no external funding.

Conflicts of Interest: The authors declare no conflict of interest.

\section{References}

1. United Nations. The World's Cities in 2016; Department of Economic and Social Affairs, United Nations: New York, NY, USA, 2016; pp. 2-3. ISBN 978-92-1-151549-7.

2. Bertram, C.; Rehdanz, K. The Role of Urban Green Space for Human Well-Being; Ifw-KIEL INSTITUTE: Kiel, Germany, 2014.

3. Department for Environment Food and Rural Affairs (defra). Attitudes and Knowledge Relating to Biodiversity and the Natural Environment, 2007-2011; Department for Environment, Food and Rural Affairs: London, UK, 2011. 
4. HM Partnerships for NHS Ashton Leigh and Wigan. A Rapid Review of the Evidence Base in Relation to Physical Activity and Green Space and Health; HM Partnerships: Liverpool, UK, 2011; Available online: http:/ /www.hegroup. org.uk/images/resources/Physical_Activity_Green_Space_Health_Report.pdf (accessed on 17 March 2017).

5. Clavin, A.A. Realising ecological sustainability in community gardens: A capability approach. Local Environ. 2011, 16, 945-962. [CrossRef]

6. Permaculture Research Institute. How Can We Connect with Nature in Our Cities? Permaculture Research Institute: Channon, Australia, 2017; Available online: https://permaculturenews.org/2017/02/20/canconnect-nature-cities / (accessed on 20 February 2017).

7. Bullivant, L. Masterplanning Futures; Routledge: London, UK, 2012; ISBN 978-0415554473.

8. Soga, M.; Gaston, K.J.; Yamaura, Y. Gardening is beneficial for health: A meta-analysis. Prev. Med. Rep. 2017, 5, 92-99. [CrossRef] [PubMed]

9. Bragg, R.; Wood, C.; Barton, J.; Pretty, J. Let Nature Feed Your Senses: Engaging People with Nature, Food and Farming; Essex Sustainability Institute and Department of Biological Sciences, University of Essex: Essex, UK, 2012.

10. Cardiff University. Community Grown Food in Wales; Cardiff University: Cardiff, UK, 2012.

11. Department of community and Local Government (DCLG). Space for Food Growing: A Guide; Department of Community and Local Government: London, UK, 2012.

12. Plymouth City Council. Derriford Community Park and One Planet Centre Masterplan Report; Plymouth City Council: Plymouth, UK, 2012.

13. Mind. Feel Better Outside, Feel Better Inside. Ecotherapy for Mental Wellbeing Resilience and Recovery; Mind: London, UK, 2013.

14. Sustain. The Benefits of Gardening and Food Growing for Health and Wellbeing; Sustain: London, UK, 2012.

15. Hayes, L. An Investigation of Local Food Movements and Their Location within Environmental History, Using Incredible Edible Todmorden as a Case Study; The Building Futures Groups: Exeter, UK, 2014.

16. Evans, D. Thrifty, green or frugal: Reflections on sustainable consumption in a changing economic climate. Geoforum 2011, 42, 550-557. [CrossRef]

17. Alexander, S. A new civilization? London surveyed 1928-1940s. Hist. Workshop J. 2007, 64, 296-320. [CrossRef]

18. Ginn, F. Dig for Victory! New histories of wartime gardening in Britain. J. Hist. Geogr. 2012, 38, $294-305$. [CrossRef]

19. Crouch, D. The allotment, landscape and locality: Ways of seeing landscape and culture. Area 1989, 21, 261-267.

20. Hawkins, J.L.; Thirlaway, K.J.; Back, K.; Clayton, D.A. Allotment gardening and other leisure activities for stress reduction and healthy ageing. Hort. Technol. 2011, 21, 577-585.

21. Speak, A.F.; Mizgajski, A.; Borysiak, J. Allotment gardens and parks: Provision of ecosystem services with an emphasis on biodiversity. Urban For. Urban Green 2015, 14, 772-781. [CrossRef]

22. Black, R.E. Taking space to grow food and community: Urban agriculture and guerrilla gardening in Vancouver. Can. J. Urban Res. 2013, 4. [CrossRef]

23. Hardman, M.; Larkham, P. Informal Urban Agriculture: The Secret Lives of Guerrilla Gardeners; Springer: London, UK, 2014; ISBN 9783319095349.

24. Warhurst, P.; Dobson, J. Incredible! Plant Veg, Grow a Revolution; Matador: Leicester, UK, 2014; ISBN 978-1783064878.

25. Department of community and Local Government (DCLG). Food Growing: Case Studies; Department of Community and Local Government: London, UK, 2012.

26. Action with Communities in Rural England (ACRE). CLP Topic Sheet: Community Food Growing; Action with Communities in Rural England: Cirencester, UK, 2012.

27. Kinnaird, M. Community Food Growing; Leeds City Council: Leeds, UK, 2012.

28. Sustain. Capital Growth: What We Learned While Creating 2012 New Community Food Growing Spaces in London; Sustain: London, UK, 2013.

29. Sheffield City Council. Green and Open Space Strategy 2010-2030; Sheffield City Council: Sheffield, UK, 2009 ; p. 65.

30. Layton-Jones, K. Uncertain Prospects: Public Parks in the New Age of Austerity; The Gardens Trust: London, UK, 2016.

31. Curtler, W.H.R. The Enclosure and Redistribution of Our Land; The Clarendon Press: Oxford, UK, 2005.

32. Boulton, M. A History of Allotments in Sheffield; Self-Publication; Margaret Boulton: Sheffield, UK, 2017; ISBN 978-1527211025. 
33. The National Allotment Society. Brief History of Allotments; The National Allotment Society: Corby, UK, 2012; Available online: https:/ / www.nsalg.org.uk/allotment-info/brief-history-of-allotments/ (accessed on 12 May 2018).

34. Miller, W. UK allotments and urban food initiatives: (limited?) potential for reducing inequalities. Local Environ. 2015, 20, 1194-1214. [CrossRef]

35. Certomà, C.; Tornaghi, C. Political gardening. Transforming cities and political agency. Local Environ. 2015, 20, 1123-1131. [CrossRef]

36. Emmett, R. Community gardens, ghetto pastoral, and environmental justice. Interdiscip. Stud. Lit. Environ. 2011, 18, 67-86. [CrossRef]

37. Adams, D.; Hardman, M.; Larkham, P. Exploring guerrilla gardening: Gauging public views on the grassroots activity. Local Environ. 2015, 20, 1231-1246. [CrossRef]

38. Barron, J. Community gardening: Cultivating subjectivities, space, and justice. Local Environ. 2016, 22, 1142-1158. [CrossRef]

39. Schwab, E.; Caputo, S.; Hernandez-Garcia, J. Urban Agriculture: Models-in-Circulation from a Critical Transnational Perspective. Landsc. Urban Plan. 2018, 170, 15-23. [CrossRef]

40. Wekerle, G.R.; Classens, M. Food production in the city: (re)negotiating land, food and property. Local Environ. 2015, 20, 1175-1193. [CrossRef]

41. Department of community and Local Government (DCLG). National Planning Policy Framework; Department of Community and Local Government: London, UK, 2012.

42. Wolch, J.R.; Byrne, J.; Newell, J. Urban green space, public health, and environmental justice: The challenge of making cities 'just green enough'. Landsc. Urban Plan. 2014, 125, 234-244. [CrossRef]

43. Ministry of Housing, Communities \& Local Government (MHCLG). Draft Revised National Planning Policy Framework; Ministry of Housing, Communities \& Local Government: London, UK, 2018.

44. Maughan, C. Urban Gardening in the Crisis Conjuncture. Exch. Warwick Res. J 2016, 4, 167-172.

45. Dempsey, N.; Burton, M.; Duncan, R. Evaluating the effectiveness of a cross-sector partnership for green space management: The case of Southey Owlerton, Sheffield, UK. Urban For. Urban Green 2016, 15, 155-164. [CrossRef]

46. Pimbert, M. Transforming Knowledge and Ways of Knowing for Food Sovereignty and Bio-Cultural Diversity; IIED: London, UK, 2006; Available online: http:/ / pubs.iied.org/G01098/ (accessed on 12 May 2018).

47. Wachsmuth, D.; Cohen, D.A.; Angelo, H. Expand the frontiers of urban sustainability. Nature 2016, 536, 391-393. [CrossRef] [PubMed]

48. Haase, D.; Kabisch, S.; Haase, A.; Andersson, E.; Banzhaf, E.; Baro, F.; Brenck, M.; Fischer, L.K.; Frantzeskaki, N.; Kabisch, N.; et al. Greening cities-To be socially inclusive? About the alleged paradox of society and ecology in cities. Habitat Int. 2017, 64, 41-48. [CrossRef]

49. De Magalhães, C.; Carmona, M. Dimensions and models of contemporary public space management in England. J. Environ. Plan. Manag. 2009, 52, 111-129. [CrossRef]

50. Azadi, H.; Hob, P.; Hafnic, E.; Zarafshanid, K.; Witloxa, F. Multi-stakeholder involvement and urban green space performance. J. Environ. Plan. Manag. 2011, 54, 785-811. [CrossRef]

51. Smith, C.R. Institutional determinants of collaboration: An empirical study of county. J. Public Admin. Res. Theory 2009, 19, 1-21. [CrossRef]

52. Department for Communities and Local Government (DCLG). The Sustainable Communities Act 2007: Update Report; The Stationary Office: London, UK, 2013.

53. Smith, H.; Perreira, M.; Hull, A.; van den Bosch, C.K. The governance of open space: Decision-making around place-keeping. In Place-Keeping: Open Space Management in Practice; Dempsey, N., Smith, H., Burton, M., Eds.; Routledge: London, UK, 2014; pp. 56-61. ISBN 978-0415856683.

54. Mathers, A.; Dempsey, N.; Molin, F.J. Place-keeping in action: Evaluating the capacity of green space partnerships in England. Landsc. Urban Plan. 2015, 139, 126-136. [CrossRef]

55. Newcastle City Council. The Future of Newcastle's Parks and Allotments. Available online: https:/ /www.newcastle. gov.uk/leisure-libraries-and-tourism/parks-and-countryside/future-newcastles-parks-and-allotments (accessed on 24 April 2018).

56. Speller, G.; Ravenscroft, N. Facilitating and evaluating public participation in urban parks management. Local Environ. 2005, 10, 41-56. [CrossRef] 
57. Forbes, S.; Cooper, D.; Kendle, A.D. The history and development of ecological landscape styles. In Urban Nature Conservation: Landscape Management in the Urban Countryside; Kendle, A.D., Forbes, S.J., Eds.; E \& FN Spon: London, UK, 1997; pp. 104-107. ISBN 978-0419193005.

58. Hofmann, M.; Westermann, J.R.; Kowarik, I.; van der Meer, E. Perceptions of parks and urban derelict land by landscape planners and residents. Urban For. Urban Green 2012, 11, 303-312. [CrossRef]

59. Rohde, C.L.E.; Kendle, A.D. Nature for people. In Urban Nature Conservation: Landscape Management in the Urban Countryside; Kendle, A.D., Forbes, S.J., Eds.; E \& FN Spon: London, UK, 1997; pp. 325-326. ISBN 978-0419193005.

60. Roovers, P.; Hermy, M.; Gulinck, H. Visitor profile, perceptions and expectations in forests from a gradient of increasing urbanisation in central Belgium. Landsc. Urban Plan. 2002, 59, 129-145. [CrossRef]

61. Dempsey, N. Funding Flexible Space. In Space for Change: The Culture of Curated Landscapes; Ivers, C., Ed.; Birkhauser: Basel, Switzerland, 2018.

62. Johnson, G.; Whittington, R.; Scholes, K. Exploring Strategy Text E Cases, 10th ed.; Pearson: London, UK, 2014; pp. 379-393. ISBN 978-1292145129.

63. Vandelanotte, K.; De Bourdeaudhuij, I. Acceptability and feasibility of a computer-tailored physical activity intervention using stages of change: Project. Health Educ. Res. 2003, 18, 304-317. [CrossRef] [PubMed]

64. Plaete, J.; De Bourdeaudhuij, I.; Verloigne, M.; Crombez, G. Acceptability, feasibility and effectiveness of an eHealth behaviour intervention using self-regulation: 'MyPlan'. Patient Educ. Couns. 2015, 98, 1617-1624. [CrossRef] [PubMed]

65. Lattie, E.G.; Ho, J.; Sargent, E.; Tomasino, K.N.; Smith, I.D.; Brown, C.H.; Mohr, D.C. Teens engaged in collaborative health: The feasibility and acceptability of an online skill-building intervention for adolescents at risk for depression. Internet Interv. 2017, 8, 15-26. [CrossRef] [PubMed]

66. Mendenhall, E.; De Silva, M.J.; Hanlon, C.; Petersen, I.; Shidhaye, R.; Jordans, M.; Luitel, M.; Sebunnya, J.; Fekadu, A.; Patel, V.; et al. Acceptability and feasibility of using non-specialist health workers to deliver mental health care: Stakeholder perceptions from the PRIME district sites in Ethiopia, India, Nepal, South Africa, and Uganda. Soc. Sci. Med. 2014, 118, 33-42. [CrossRef] [PubMed]

67. Sheffield City Council. Site Categorisation Strategy: A Guide for Adopting a More Strategic Approach to the Management, Maintenance and Development of Sheffield's Leisure and Recreational Green Spaces; Sheffield City Council: Sheffield, UK, 2000.

68. Department for Communities and Local Government (DCLG). English Indices of Deprivation 2015; Department for Communities and Local Government: London, UK, 2015.

69. Greenhalgh, L.; Parsons, A. Raising the Standard: The Green Flag Award Guidance Manual; CABE: London, UK, 2004.

70. Pettit, J. Identifying strengths and weaknesses of landscape visualisation for effective communication of future alternatives. Landsc. Urban Plan. 2011, 100, 231-241. [CrossRef]

71. Deshpande, A.D.; Baker, E.A.; Lovegreen, S.L.; Brownson, R.C. Environmental correlates of physical activity among individuals with diabetes in the rural midwest. Diabetes Care 2005, 28, 1012-1018. [CrossRef] [PubMed]

72. Giles-Corti, B.; Broomhall, M.H.; Knuiman, M.; Collins, C.; Douglas, K.; Ng, K.; Lange, A.; Donovan, R.J. Increasing walking: How important is distance to, attractiveness, and size of public open space? Am. J. Prev. Med. 2005, 28, 169-176. [CrossRef] [PubMed]

73. McCormack, G.R.; Rock, M.; Toohey, A.M.; Hignell, D. Characteristics of urban parks associated with park use and physical activity: A review of qualitative research. Health Place 2010, 16, 712-726. [CrossRef] [PubMed]

74. Wilson, D.K.; Kirtland, K.A.; Ainsworth, B.E.; Addy, C.L. Socioeconomic status and perceptions of access and safety for physical activity. Ann. Behav. Med. 2004, 28, 20-28. [CrossRef] [PubMed]

75. Moore, L.V.; Diez Roux, A.V.; Evenson, K.R.; McGinn, A.P.; Brines, S.J. Availability of recreational resources in minority and low socioeconomic status areas. Am. J. Prev. Med. 2008, 34, 16-22. [CrossRef] [PubMed]

76. Dahmann, N.; Wolch, J.; Joassart-Marcelli, P.; Reynolds, K.; Jerrett, M. The active city? Disparities in provision of urban public recreation resources. Health Place 2010, 16, 431-445. [CrossRef] [PubMed]

77. Peschardt, K.K.; Schipperijn, J.; Stigsdotter, U.K. Use of small public urban green spaces (SPUGS). Urban For. Urban Green 2012, 11, 235-244. [CrossRef] 
78. Cohen, D.A.; Lapham, S.; Evenson, K.R.; Williamson, S.; Golinelli, D.; Ward, P.; Hillier, A.; McKenzie, T.L. Use of neighbourhood parks: Does socio-economic status matter? A four-city study. Public Health 2013, 127, 325-332. [CrossRef] [PubMed]

79. Zhang, Y.; van Dijk, T.; Tang, J.; van den Berg, A.E. Green Space Attachment and Health: A Comparative Study in Two Urban Neighborhoods. Int. J. Environ. Res. Public Health 2015, 12, 14342-14363. [CrossRef] [PubMed]

80. Zhang, Y.; Van den Berg, A.E.; Van Dijk, T.; Weitkamp, G. Quality over Quantity: Contribution of Urban Green Space to Neighborhood Satisfaction. Int. J. Environ. Res. Public Health 2017, 14, 535. [CrossRef] [PubMed]

81. Beyer, K.M.; Kaltenbach, A.; Szabo, A.; Bogar, S.; Nieto, F.J.; Malecki, K.M. Exposure to Neighborhood Green Space and Mental Health: Evidence from the Survey of the Health of Wisconsin. Int. J. Environ. Res. Public Health 2014, 11, 3453-3472. [CrossRef] [PubMed]

82. Coolen, H.; Meesters, J. Private and public green spaces: Meaningful but different settings. J. Hous. Built Environ. 2012, 27, 49-67. [CrossRef]

83. Gaube, V.; Remesch, A. Impact of urban planning on household's residential decisions: An agent-based simulation model for Vienna. Environ. Model. Softw. 2013, 45, 92-103. [CrossRef] [PubMed]

84. Houlden, V.; Weich, S.; Jarvis, S. A cross-sectional analysis of green space prevalence and mental wellbeing in England. BMC Public Health 2017, 17, 460. [CrossRef] [PubMed]

85. Steele, J.; Bourke, L.; Luloff, A.E.; Liao, P.-S.; Theodori, G.L.; Krannich, R.S. The drop-off/Pick-up method for household survey research. Community Dev. J. 2001, 32, 238-250. [CrossRef]

86. Riley, P.J.; Kiger, G. Increasing survey response: The drop-off/pick-up technique. Rural Sociol. 2002, $22,6-10$.

87. Punch, K.F. Introduction to Social Research: Quantitative \& Qualitative Approaches, 3rd ed.; SAGE: London, UK, 2014; p. 144. ISBN 978-1446240939.

88. Donovan, J.; Sanders, C. Key Issues in the Analysis of Qualitative Data. In Handbook of Health Research Methods: Investigation, Measurement and Analysis; Bowling, A., Ebrahim, S., Eds.; Open University Press: Maidenhead, UK, 2005; pp. 520-521. ISBN 978-0335214600.

89. Braun, V.; Clarke, V. Using thematic analysis in psychology. Qual. Res. Psychol. 2006, 3, 77-101. [CrossRef]

90. Tesch, R. Qualitative Research: Analysis Types and Software Tools; Falmer Press: London, UK, $1990 ;$ p. 51. ISBN 978-1850006091.

91. NatCen Learning. The Framework Approach to Qualitative Data Analysis; NatCen Learning: London, UK, 2012.

92. Fisher, D.R.; Svendsen, E.S.; Connolly, J.J.T. Urban Environmental Stewardship and Civic Engagement: How Planting Trees Strengthens the Roots of Democracy; Routledge Press: New York, NY, USA, 2015; pp. 91-114. ISBN 978-0415723633.

93. Heritage Lottery Fund. State of UK Public Parks 2014; Heritage Lottery Fund: London, UK, 2014.

94. Sharp, N.; Royal, S. Friends Groups_Adding Value to Parks Services, National Federation of Parks and Green Spaces; The National Federation of Parks and Green Spaces: Birmingham, UK, 2017; Available online: https:/ / www.natfedparks.org.uk/word/nfpgs-friends-groups-adding-value.doc/ (accessed on 12 May 2018).

(C) 2018 by the authors. Licensee MDPI, Basel, Switzerland. This article is an open access article distributed under the terms and conditions of the Creative Commons Attribution (CC BY) license (http:/ / creativecommons.org/licenses/by/4.0/). 